\title{
B-cell Function in Newborn Infants of Diabetic Mothers
}

\author{
Lise G. Heding ${ }^{1}$, B. Persson ${ }^{2}$, and M. Stangenberg ${ }^{2}$ \\ ${ }^{1}$ Novo Research Institute, Copenhagen, Denmark, and ${ }^{2}$ Department of Pediatrics, St. Göran's Hospital, and Department of Obstetrics, \\ Sabbatberg's Hospital, Karolinska Institutet, Stockholm, Sweden
}

Summary. Serum concentrations of glucose, C-peptide, IRI (Immunoreactive insulin) and proinsulin were determined in 31 insulin-dependent diabetic mothers and their newborn infants and in 13 nondiabetic mothers and their babies at the time of delivery. Eleven mothers with long-term diabetes had insulin antibodies and low or undetectable C-peptide levels (mean \pm SEM: $0.04 \pm 0.01 \mathrm{nmol} / \mathrm{l}$ ). Diabetic mothers without insulin antibodies had a mean Cpeptide value of $1.18 \mathrm{nmol} / 1$ (range $0.05-3.00$ ) and the non-diabetics $0.95 \mathrm{nmol} / 1(0.28-2.4)$. Blood glucose values ( 2 to 4 hours after birth) of less than $1.7 \mathrm{mmol} / \mathrm{l}$ were observed in 7 of the 11 babies with antibodies and in 3 of the 20 babies without antibodies. C-peptide in the 31 babies of diabetic mothers correlated to maternal glucose $(\mathrm{p}<0.05)$. In addition the mean glucose value ( $2-4$ hours) was negatively correlated to IRI and proinsulin $(\mathrm{p}<0.01)$ in the babies without antibodies, confirming that elevated maternal glucose leads to increased insulin secretion at the time of birth, which may lead to hypoglycaemia. In babies without antibodies birth weight correlated to their C-peptide $(\mathrm{p}<0.01)$ and proinsulin $(\mathrm{p}<0.01)$. The 31 babies of the diabetic mothers were born with higher $C$-peptide $(1.01 \pm 0.16 \mathrm{nmol} /$ l) than babies of non-diabetic mothers $(0.39 \pm 0.04$ $\mathrm{nmol} / \mathrm{l})$. The newborn infants secrete significantly more proinsulin than their mothers. Babies of mothers with insulin antibodies were born with the same concentrations of antibodies (Pearson correlation coefficient $=0.98$ ) as in their mothers, but total IRI was higher in these babies, due in part to human proinsulin being bound to the antibodies. There were significant correlations between insulin antibodies on the one hand, and IRI, proinsulin and C-peptide on the other, in the 11 babies, $p<0.001$, $p<0.001$ and $p<0.01$, respectively, the last indicating increasing $\mathrm{B}$-cell activity with higher antibody levels.
Key words: Insulin, C-peptide, proinsulin, diabetic mothers, infants, neonatal hypoglycaemia.

Insulin antibodies cross the placenta and are found in the blood of newborn infants of diabetic mothers who have developed antibodies during insulin treatment [1-4]. These antibodies make it impossible to measure insulin by radioimmunoassay in the evaluation of B-cell function either in the babies or in the mothers $[2,5,6]$. Block et al. [5] determined the total Cpeptide immunoreactivity (CPR) in diabetic mothers and their newborn and found that a high proportion of the CPR was proinsulin. The study did not, however, report absolute concentrations of C-peptide and proinsulin so there was no basis for comparing Bcell activity in infants of diabetic mothers with that of control infants. Phelps et al. [6] determined C-peptide in 9 infants of normal mothers and 9 infants born of diabetic mothers, 8 of whom had antibodies, after removing proinsulin with polyethylene glycol. Unfortunately, the two groups of babies had different mean basal glucose: $70 \mathrm{mg} / \mathrm{dl}$ in the normal group and $39 \mathrm{mg} / \mathrm{dl}$ in the diabetic group. In spite of this, mean C-peptide concentration tended to be higher in the infants of diabetic mothers.

In the present study, B-cell activity has been assessed, by determining IRI, C-peptide and proinsulin, in non-diabetic and diabetic mothers and their babies at the time of delivery and blood glucose was determined in the babies at 2 to 4 hours after birth and prior to feeding. The aims of the investigation were:

1) to compare B-cell activity in mothers and babies;

2) to compare B-cell activity in infants of diabetic and non-diabetic mothers; 
Table 1. Clinical data on diabetic mothers and their infants, subdivided according to presence or absence of insulin binding antibodies

\begin{tabular}{|c|c|c|}
\hline & $\begin{array}{l}\text { Antibodies } \\
\text { present }\end{array}$ & $\begin{array}{l}\text { Antibodies } \\
\text { absent }\end{array}$ \\
\hline Mothers (n) & 11 & 20 \\
\hline Age, years & $26 \pm 4$ & $29 \pm 5$ \\
\hline Duration of diabetes (years) & $13 \pm 6$ & $1.2 \pm 4.3$ \\
\hline White's classes (n) & $3 \mathrm{~B}, 4 \mathrm{C}, 4 \mathrm{D}$ & $1 \mathrm{~A}, 18 \mathrm{~B} 1 \mathrm{D}$ \\
\hline Maximum insulin dose & & \\
\hline during pregnancy, IU/day & $73 \pm 32$ & $27 \pm 33$ \\
\hline $\begin{array}{l}\text { Mean glucose level } \\
\text { (last trimester) mmol/l }\end{array}$ & $5.9 \pm 1.3$ & $4.8 \pm 1.5(17)$ \\
\hline Mode of delivery $(\mathrm{n})$ & & \\
\hline vaginal & 2 & 13 \\
\hline Caesarean section & 9 & 7 \\
\hline \multicolumn{3}{|l|}{ Infants } \\
\hline Gestational age, days & $260 \pm 9$ & $266 \pm 7$ \\
\hline Birth weight, $\mathrm{g}$ & $3419 \pm 438$ & $3703 \pm 812$ \\
\hline Length, cm & $49 \pm 2$ & $51 \pm 2$ \\
\hline Birth weight percentile & $58 \pm 26$ & $59 \pm 31$ \\
\hline Sex, number $\quad 0^{x}$ & $\begin{array}{l}6 \\
5\end{array}$ & $\begin{array}{r}11 \\
9\end{array}$ \\
\hline $\begin{array}{l}\text { Blood glucose, } \mathrm{mmol} / \mathrm{I} \\
\text { at } 2-4 \text { hours }\end{array}$ & $2.1 \pm 1.3$ & $2.4 \pm 0.8(18)$ \\
\hline
\end{tabular}

Ratio are given as mean \pm SD

When samples were not obtained for all subjects, the number is given in parantheses

3) to discover the effect of insulin antibodies on B-cell activity in newborn babies; and

4) to seek possible correlations between birth weight, occurence of hypoglycaemia and B-cell activity.

\section{Materials and Methods}

\section{Patients}

A total of 31 diabetic pregnancies were studied: 1 White class $A$, 21 class B, 4 class $\mathrm{C}$ and 5 class D. Among the 21 class $\mathrm{B}$ cases there were 12 patients with gestational diabetes who needed insulin treatment during pregnancy. One baby (class B) died in the immediate neonatal period because of severe congenital anomalies. Management of the pregnant mothers and their infants followed the same principles as previously reported [7, 8]. Maternal and infant characteristics are given in Table 1. The data have been divided into two groups depending on the presence or not of insulin binding antibodies in maternal and fetal blood at delivery. The degree of metabolic control achieved during the last trimester of pregnancy was assessed as the mean of four daily blood glucose determinations from the 32nd week of pregnancy until delivery. Blood glucose in the neonates was determined in all infants at 2 to $4 \mathrm{~h}$ after birth, before the first feed. None of the infants presented clinical evidence of hypoglycaemia. Asymptomatic hypolycaemia was defined as a mean glucose value $<1.7 \mathrm{mmol} / 1$.

The control group comprised 13 non-diabetic pregnancies. The average age of the mothers was 30 years (range 27-37). Eight infants were delivered by elective cesarean section, five were delivered vaginally. There were 6 girls and 7 boys. The average birth weight was $3468 \mathrm{~g} \pm 401$ (SD), the mean birth weight percentile was $48 \pm 29$, mean body length $50 \mathrm{~cm} \pm 2$ and the mean gestational age was $275 \pm 8$ days. All infants had an uneventful neonatal course.

\section{Blood Samples}

Maternal peripheral venous blood and umbilical cord blood was drawn simultaneously immediately after delivery; the serum was stored at $-20^{\circ} \mathrm{C}$ until use in the assays.

\section{Analyses}

Insulin binding to IgG was determined by immunoelectrophoresis according to [9] and the binding capacity (U/1) calculated.

In samples containing insulin antibodies, serum was extracted with acid ethanol [10] prior to the determination of IRI, proinsulin and C-peptide. The neutral extract was used for analyses for IRI, C-peptide (after removal of proinsulin), and proinsulin. IRI was determined according to [10], detection limit ( $=2 \mathrm{SD}$ from zero): $1 \mathrm{mU} / 1$ and a coefficient of variation (day to day) of $10 \%$, and Cpeptide after binding of proinsulin to insulin antibodies covalently attached to Sepharose particles (S-AIS). The assay had a detection limit of $0.01 \mathrm{nmol} / 1$ and a coefficient of variation of $7 \%$ [11]. Proinsulin was determined bound to S-AIS [12], the assay had a detection limit of $0.002 \mathrm{nmol} / 1$ and a coefficient of variation of $12 \%$. Glucose was determined in serum by the glucose oxidase method. The statistic evaluation was performed using pair-wise t-test, and correlation analyses (Pearson and Spearman-Rank). Results are presented as mean \pm SEM unless otherwise stated.

\section{Results}

\section{Serum Glucose, IRI, C-peptide and Proinsulin}

Serum glucose (at birth), IRI, C-peptide and proinsulin in the mother-infant groups are shown in Table 2. Data on the 11 patients with insulin antibodies (IgG from 0.241 to 5.039; mean 1.922 and median $1.920 \mathrm{U} / 1)$ are shown separately, since the antibodies affect the IRI and proinsulin levels invalidating direct comparison with the other patients. Serum glucose was higher in all three groups of mothers than in their babies. The three groups of babies had similar and not statistically different mean glucose values: 4.04 , 4.48 and $5.70 \mathrm{mmol} / 1$, respectively, and the lowest glucose values at birth recorded in the three groups were also similar, at $1.60,1.39$ and $1.98 \mathrm{mmol} / 1$.

Total serum IRI in the group with antibodies was grossly elevated in both mothers and infants due to the formation of antibody complexes. In the diabetics without antibodies, IRI, consisting of both exogenous and endogenous insulin was similar $(25 \pm 3 \mathrm{mU} / \mathrm{l})$ to that in non-diabetic mothers $(21 \pm 7 \mathrm{mU} / \mathrm{l})$. The infants of these diabetic mothers had higher IRI (47 $\pm 12 \mathrm{mU} / \mathrm{l})$ than their mothers in contrast to the control group. Thus, there was a significant difference between the IRI value in the group of infants of the 
Table 2. Serum glucose, total IRI, C-peptide and proinsulin in mothers and babies at the time of birth. Group I: 11 diabetics with antibodies - Group II: 20 diabetics without antibodies - Group III: 13 non-diabetics

\begin{tabular}{|c|c|c|c|c|c|c|c|c|c|c|c|}
\hline & \multirow[b]{2}{*}{ Group } & \multicolumn{5}{|c|}{ Mothers } & \multicolumn{5}{|c|}{ Babies } \\
\hline & & mean & $\mathrm{SD}$ & SEM & Median & Range & mean & $\mathrm{SD}$ & SEM & Median & Range \\
\hline $\begin{array}{l}\text { Glucose } \\
\mathrm{mmol} / 1\end{array}$ & $\begin{array}{l}\text { I } \\
\text { II } \\
\text { III }\end{array}$ & $\begin{array}{l}8.8 \\
6.4 \\
4.3\end{array}$ & $\begin{array}{l}4.2 \\
3.2 \\
1.0\end{array}$ & $\begin{array}{l}1.2 \\
0.8 \\
0.2\end{array}$ & $\begin{array}{r}10.0 \\
6.5 \\
4.3\end{array}$ & $\begin{array}{l}1.5-14.9 \\
2.6-15.7 \\
2.9-6.4\end{array}$ & $\begin{array}{l}5.7 \\
4.5 \\
4.0\end{array}$ & $\begin{array}{l}3.1 \\
2.0 \\
1.4\end{array}$ & $\begin{array}{l}0.8 \\
0.5 \\
0.4\end{array}$ & $\begin{array}{l}4.9 \\
3.9 \\
3.6\end{array}$ & $\begin{array}{l}1.6-11.1 \\
1.4-8.6 \\
2.0-7.3\end{array}$ \\
\hline $\begin{array}{l}\text { Total IRI } \\
\mathrm{mU} / \mathrm{l}\end{array}$ & $\begin{array}{l}\text { I } \\
\text { II } \\
\text { III }\end{array}$ & $\begin{array}{r}297 \\
25 \\
21\end{array}$ & $\begin{array}{r}295 \\
12 \\
25\end{array}$ & $\begin{array}{r}89 \\
3 \\
7\end{array}$ & $\begin{array}{r}176 \\
26 \\
15\end{array}$ & $\begin{array}{c}45-944 \\
0-42 \\
6-103\end{array}$ & $\begin{array}{r}450 \\
47 \\
13\end{array}$ & $\begin{array}{r}508 \\
53 \\
7\end{array}$ & $\begin{array}{r}153 \\
12 \\
2\end{array}$ & $\begin{array}{r}355 \\
29 \\
11\end{array}$ & $\begin{array}{l}19-1792 \\
3-205 \\
4-32\end{array}$ \\
\hline $\begin{array}{l}\text { C-peptide } \\
\mathrm{nmol} / 1\end{array}$ & $\begin{array}{l}\text { I } \\
\text { II } \\
\text { III }\end{array}$ & $\begin{array}{l}0.043 \\
1.180 \\
0.945\end{array}$ & $\begin{array}{l}0.020 \\
0.886 \\
0.577\end{array}$ & $\begin{array}{l}0.006 \\
0.198 \\
0.160\end{array}$ & $\begin{array}{l}0.050 \\
0.975 \\
0.800\end{array}$ & $\begin{array}{l}0-080 \\
0.050-3.000 \\
0.280-2.400\end{array}$ & $\begin{array}{l}1.095 \\
0.963 \\
0.394\end{array}$ & $\begin{array}{l}0.767 \\
0.963 \\
0.173\end{array}$ & $\begin{array}{l}0.231 \\
0.215 \\
0.048\end{array}$ & $\begin{array}{l}0.780 \\
0.540 \\
0.320\end{array}$ & $\begin{array}{l}0.330-2.750 \\
0.250-4.000 \\
0.200-0.680\end{array}$ \\
\hline $\begin{array}{l}\text { Proinsulin } \\
\mathrm{nmol} / 1\end{array}$ & $\begin{array}{l}\text { I } \\
\text { II } \\
\text { III }\end{array}$ & $\begin{array}{l}0.032 \\
0.058 \\
0.046\end{array}$ & $\begin{array}{l}0.033 \\
0.064 \\
0.034\end{array}$ & $\begin{array}{l}0.010 \\
0.014 \\
0.009\end{array}$ & $\begin{array}{l}0.043 \\
0.034 \\
0.043\end{array}$ & $\begin{array}{l}0-0.080 \\
0-0.200 \\
0.007-0.135\end{array}$ & $\begin{array}{l}2.388 \\
0.238 \\
0.073\end{array}$ & $\begin{array}{l}2.417 \\
0.328 \\
0.032\end{array}$ & $\begin{array}{l}0.729 \\
0.073 \\
0.010\end{array}$ & $\begin{array}{l}1.050 \\
0.104 \\
0.066\end{array}$ & $\begin{array}{l}0.038-7.250 \\
0.015-1.350 \\
0.032-0.120\end{array}$ \\
\hline
\end{tabular}

Table 3. Proinsulin in 13 non-diabetic mothers and babies and 20 gestational diabetics without insulin antibodies and their babies

\begin{tabular}{|c|c|c|c|c|c|}
\hline & & & \multicolumn{3}{|l|}{ Proinsulin } \\
\hline & & & $\mathrm{nmol} / \mathrm{l}$ & $\%$ of IRI & $\%$ of C-peptide \\
\hline $\begin{array}{l}\text { Control } \\
\text { group }\end{array}$ & $\begin{array}{l}\text { Mothers } \\
\text { Babies }\end{array}$ & $\begin{array}{l}\text { mean } \\
\text { range } \\
\text { mean } \\
\text { range }\end{array}$ & $\begin{array}{l}0.046 \\
0.007-0.135 \\
0.073 \\
0.032-0.120\end{array}$ & $\begin{array}{l}25^{\mathrm{a}} \\
11-45 \\
61^{\mathrm{a}} \\
29-100\end{array}$ & $\begin{array}{l}5^{\mathrm{b}} \\
3-9 \\
11^{\mathrm{b}} \\
10-33\end{array}$ \\
\hline $\begin{array}{l}\text { Diabetic } \\
\text { group }\end{array}$ & $\begin{array}{l}\text { Mothers } \\
\text { Babies }\end{array}$ & $\begin{array}{l}\text { mean } \\
\text { range } \\
\text { mean } \\
\text { range }\end{array}$ & $\begin{array}{l}0.058 \\
0-0.200 \\
0.238 \\
0.015-1.350\end{array}$ & $\begin{array}{l}- \\
-\end{array}$ & $\begin{array}{l}3^{a} \\
1-7 \\
26^{a} \\
3-75\end{array}$ \\
\hline
\end{tabular}

\footnotetext{
${ }^{a}$ Difference between mothers and babies stat.sign. $\mathrm{p}<0.01$

${ }^{b}$ Difference between mothers and babies stat.sign. $\mathrm{p}<0.001$

Pairwise t-test used for the calculation of the p-values
}

diabetic mothers without antibodies $(47 \pm 12 \mathrm{mU} / \mathrm{l})$, and the control infants $(13 \pm 2 \mathrm{mU} / \mathrm{l}), \mathrm{p}<0.01$ (Wilcoxon's two sample tests).

Serum C-peptide levels in the long-term diabetics with antibodies were very low (from 0 to $0.08 \mathrm{nmol} / \mathrm{l}$ ) in contrast to their infants $(1.10 \pm 0.23 \mathrm{nmol} / \mathrm{l})$. The insulin-treated mothers without antibodies, who became diabetic shortly before or during pregnancy, had C-peptide similar to the control group of mothers $(1.18 \pm 0.20$ versus $0.95 \pm 0.16 \mathrm{nmol} / \mathrm{l})$. The 31 infants of the diabetic mothers showed far higher C-peptide values than the controls (1.01 \pm 0.16 vs. $0.39 \pm 0.04 \mathrm{nmol} / 1, \mathrm{p}<0.001$ ).

Serum proinsulin levels were low or nil in the diabetic mothers with antibodies (mean \pm SEM: $0.032 \pm$ $0.010 \mathrm{nmol} / \mathrm{l})$, whereas their infants showed abnormally high concentrations due to the binding to insulin antibodies. In the two other groups, proinsulin in the infants was considerably higher than in the mothers. Table 3 shows proinsulin calculated as percent of IRI $(0.01 \mathrm{nmol} / 1$ of proinsulin reacts as $1 \mathrm{mU} / 1$ in the insulin immunoassay) and of the C-peptide in the control group and in the diabetic group without antibodies. Both absolute and relative amounts of proinsulin were increased. Proinsulin as percent of IRI could not be calculated in the mothers. However, as percent of C-peptide, proinsulin was higher in the infants than in their mothers $(26 \%$ and $3 \%$, $\mathrm{p}<0.01$ ). All babies in the control group had higher percent proinsulin of IRI and C-peptide than their mothers.

\section{Insulin Antibodies and B-cell Activity}

Figure 1 shows the correlation between insulin binding antibodies in 10 mothers and babies, the correlation coefficient being $0.98(p<0.001)$. (Insulin antibodies were not determined in one of the mothers 
$\mathrm{mU} / \mathrm{ml}$

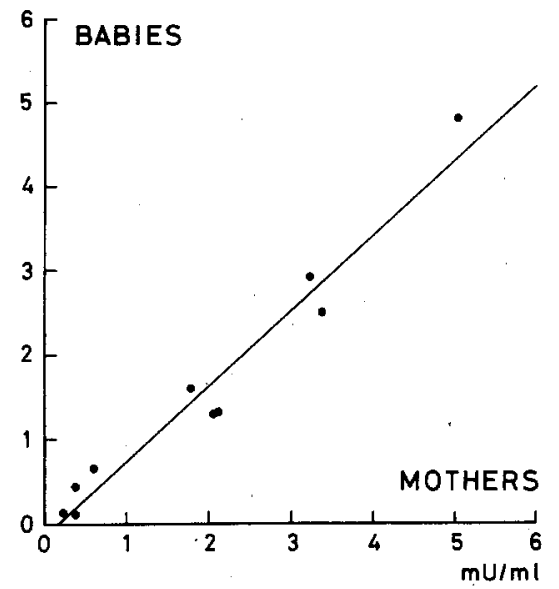

Fig. 1. Relation of insulin binding IgG in diabetic mothers and in their babies at the time of birth. Correlation coefficient $r=0.978$, $\mathrm{p}<0.001$

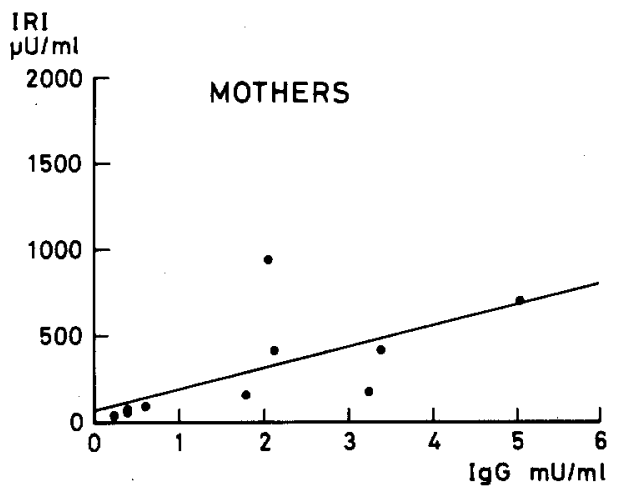

IR I

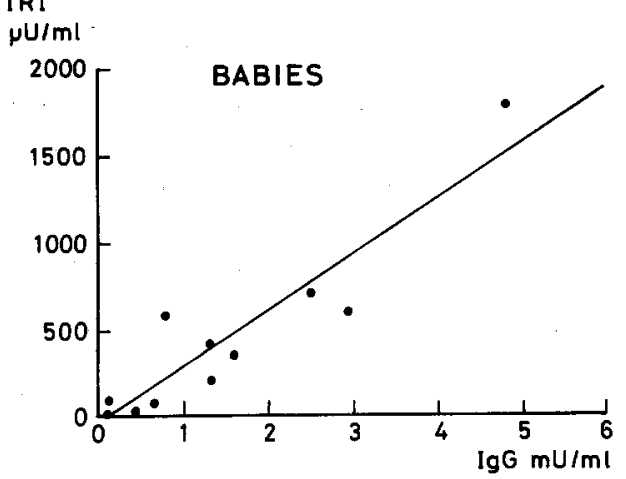

Fig. 2. Correlations between serum insulin binding IgG and serum total IRI in the diabetic mothers with antibodies and their babies. Correlation coefficient between IRI and IgG in mothers, $r=0.632$, $\mathrm{p}<0.05$, and in the babies, $\mathrm{r}=0.923, \mathrm{p}<0.001$

due to lack of serum). Figure 2 shows the correlation between insulin binding IgG and IRI in mothers and babies; a significant correlation between IRI and antibodies was observed in both groups. The same amount of antibodies was associated with a higher
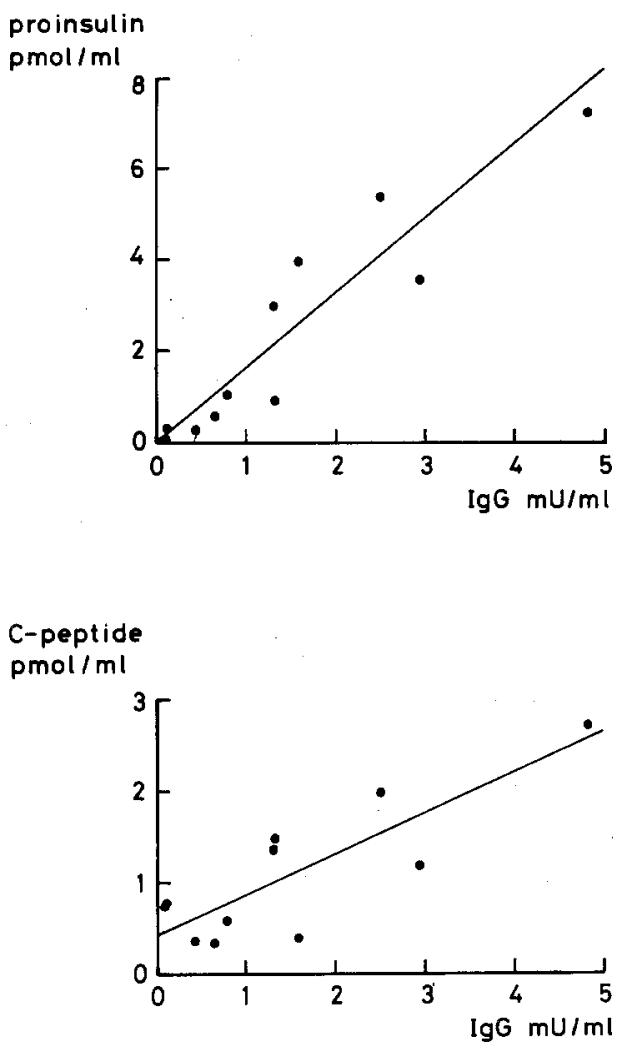

Fig. 3. Correlations between insulin binding to $\operatorname{IgG}$ and serum proinsulin and $\mathrm{C}$-peptide in the babies of diabetic mothers with antibodies. Correlation coefficient between proinsulin and $\mathrm{IgG}$, $\mathrm{r}=0.928, \mathrm{p}<0.001$ and between C-peptide and $\operatorname{IgG}, \mathrm{r}=0.827$, $\mathrm{p}<0.01$

total IRI concentration in the infants than in the mothers. The insulin binding antibodies were also correlated to proinsulin and C-peptide, with correlation coefficients of 0.93 and 0.83 , respectively (Fig. 3).

\section{IRI, C-peptide and Glucose Correlations}

IRI and C-peptide in the non-diabetic group were well correlated both in the mothers $(p<0.001)$ and in the infants $(p<0.001)$. In contrast, there was no such correlation in either the insulindependent diabetic mothers or in their infants. Glucose was correlated to C-peptide and IRI in the non-diabetic mothers (both $\mathrm{p}<0.05$ ), and glucose to IRI in the diabetic mothers without antibodies $(p<0.05)$. There was also a correlation between C-peptide in all babies of diabetic mothers and glucose in the mothers at the time of birth $(p<0.05)$.

\section{Birth Weight, Hypoglycaemia and B-cell Activity}

Babies with antibodies weighed from $2800 \mathrm{~g}$ to $4200 \mathrm{~g}(3419 \pm 438 \mathrm{~g})$ at birth, similar to the normal 
group, 3000 to $4250 \mathrm{~g}$ ( $3468 \pm 401 \mathrm{~g}$ ). In the group with antibodies there was no correlation between birth weight and total IRI, antibodies, C-peptide and proinsulin. Asymptomatic hypoglycaemia 2-4 h after birth was present in 7 of the 11 infants with antibodies, but there was no correlation between the post-birth glucose and C-peptide, proinsulin, total IRI and antibodies.

The babies of diabetic mothers without antibodies weighed from 2700 to $5700 \mathrm{~g}$ (mean $3703 \pm$ $812 \mathrm{~g}$ ). There was a positive correlation between birth weight and C-peptide and proinsulin $(\mathrm{p}<0.001$ and 0.01 ). Three of the 20 infants developed asymptomatic hypoglycaemia and in this group negative correlations were found between post-birth glucose and C-peptide $(\mathrm{p}<0.01)$, proinsulin $(\mathrm{p}<0.01)$ and IRI ( $p<0.01)$ (Pearson correlation analysis). Using the Spearman Rank correlation analysis significant relations were maintained for all except for the relations between the proinsulin and birth weight and between 2 to $4 \mathrm{~h}$ glucose and C-peptide.

\section{Discussion}

\section{B-cell Activity in Mothers and Infants with Insulin Antibodies}

The presence of insulin antibodies made it necessary to analyse the samples from this group separately, performing an acid extraction of the serum prior to determination of IRI, C-peptide and proinsulin in order to obtain meaningful results. Thus earlier reports, where IRI has been measured in antibodycontaining diabetic sera $[2,13]$ or in diabetic sera where absence of antibodies has not been shown [14], are not valid for a comparison of B-cell activity in diabetic mothers and their babies with that of a control group. The finding of nearly identical levels of insulin binding antibodies in mother and infant at the time of delivery $(p<0.001)$ confirms earlier observations $[1,3,4]$.

The 11 mothers had very low or undetectable Cpeptide, as would be expected in young insulindependent diabetics (aged $26 \pm 4$ years) with a mean diabetes duration of $13 \pm 6$ years. The babies had high concentrations of C-peptide.

Proinsulin was found in 6 of the mothers with antibodies, but in low concentrations considering the concentrations of insulin antibodies. In contrast the babies had very high amounts of bound proinsulin circulating. There was no indication of C-peptide from the babies having crossed the placenta (there was a negative correlation between the levels of Cpeptide in babies and mothers $\mathrm{p}<0.05$ ). The concentration of antibody bound proinsulin in the babies (mean 2.388 , range $0.038-7.250 \mathrm{nmol} / \mathrm{l}$ ) was correlated to the bound proinsulin in the mothers (mean 0.032 , range $0-0.080 \mathrm{nmol} / 1$ with a $\mathrm{p}$-value $<0.05$ ). Hence it is possible that some of the proinsulin antibody complexes pass the placenta.

Total IRI was correlated to the insulin binding IgG in the mothers $(p<0.05)$ and the babies $(p<$ 0.001 ). Mean total IRI was about twice as high in the babies as in the mothers, although they had the same amount of insulin antibodies. This difference could be explained by the high concentrations of bound proinsulin in the babies.

There was a significant correlation between antibodies and $\mathrm{C}$-peptide in the babies $(\mathrm{p}<0.01)$ and as $\mathrm{C}$-peptide is not bound to antibodies the correlation is a consequence of an increased insulin secretion. Hence a high concentration of insulin antibody complexes may require increased endogenous insulin secretion caused by the constant amount of insulin required to keep the concentration of insulin antibody complexes nearly constant.

\section{B-cell Activity in Mothers and Infants without Antibodies}

The diabetic mothers had C-peptide levels similar to the controls. Nevertheless, they were hyperglycaemic at the time of birth $(6.44 \mathrm{mmol} / \mathrm{l})$ and required insulin treatment. Block et al. [5] found higher CPR (Cpeptide reactivity) in gestational diabetes than in the controls. However, their diabetic mothers had antibodies whose CPR was shown to be constituted by large amounts of proinsulin besides C-peptide. The patients reported by Phelps et al. [6] had had diabetes for 0-21 years. From the present results it appears that diabetic mothers with a short duration of diabetes (1 A, $18 \mathrm{~B}$ and $1 \mathrm{D}$ White's classes) have an insufficient B-cell activity since they require exogenous insulin to reduce hyperglycaemia.

Serum proinsulin concentration was slightly higher in the diabetics than in the control mothers. In contrast the babies of the diabetic mothers showed a B-cell activity quite different from that of the control babies. Serum IRI, C-peptide and proinsulin levels were approximately three times as high as in the controls, in spite of a rather small difference in glucose between the two groups at the time of birth (Figs. 1-3). This finding using specific C-peptide determination in a large number of neonates suggests that babies of diabetic mothers have hypersecretion of insulin at the time of birth. Earlier reports reached the same conclusion, but they were based on determination in the presence of antibodies $[2,13,14]$ or measurement of CPR [5]. Phelps et al. [6] investigated the babies 2 to 4 hours after birth and found 
similar C-peptide in babies of controls and diabetics, but lower glucose in the infants of the diabetics. The findings reported here are in agreement with others $[15,16]$ who found higher IRI in babies of untreated gestational diabetes and diabetes of short duration than in normal babies. The reason for this B-cell hypersecretion is still an enigma, but possibly the maternal hyperglycaemia enhances the B-cell secretion of the babies.

A remarkable difference, previously unreported, was observed between proinsulin in babies and mothers in the control group, as well as in the diabetics without antibodies. Proinsulin was markedly increased in the babies as compared to the mothers not only absolutely, but also in relation to IRI and Cpeptide in the control group $(\mathrm{p}<0.01$ and 0.001$)$ and to $C$-peptide in the diabetic group $(\mathrm{p}<0.01)$. The reason for this hypersecretion of proinsulin in the newborn is unknown; possibly the $\mathbf{B}$-cells are not mature with fully developed storage granules to ensure complete conversion of the precursor proinsulin to insulin and C-peptide. This also agrees with the finding that the babies of diabetics with a shorter gestational age had a more pronounced hypersecretion of proinsulin.

\section{Birth Weight, Hypoglycaemia and B-cell Activity}

The gestational age was shorter in the two diabetic groups ( $\sim 260$ days) than in the control group (275 days) whereas the mean birth weights were 3414 and $3703 \mathrm{~g}$ in the diabetics and $3468 \mathrm{~g}$ in the controls.

The reason for the higher frequency of asymptomatic hypoglycaemia in 7 of 11 babies with antibodies and only 3 of 20 babies without antibodies cannot be explained. It is possible that the release of insulin from the insulin-antibody complexes in the post-natal period prior to feeding gives a higher risk, but numerous other factors may be important. In the babies without antibodies the positive correlations between birth weight and C-peptide and proinsulin agree with the hypothesis about hyperinsulinism being partly responsible for the increased weight of newborns of diabetics.

Also of interest were the negative correlations between post-birth serum glucose and serum IRI, Cpeptide and proinsulin levels which were found in the babies without antibodies. Thus an enhanced B-cell activity at the time of birth is decisive for the development of hypoglycaemia. Proinsulin may play an important role due to its long half-life and high concentration in the babies of diabetic mothers and the biological activity of proinsulin in vivo being about $40 \%$ of that of insulin, but with a more protracted action (Heding, unpublished observations).
Acknowledgements. We wish to thank Mrs Bente Hansen and Mrs Marianne Heiden for their skilled technical assistance and Mrs Birgit Jensen for making the statistical calculations.

\section{References}

1. Spellacy WN, Goetz FC (1963) Insulin antibodies in pregnancy. Lancet II: 222-224

2. Jørgensen KR, Deckert T, Mølsted-Pedersen L, Pedersen J (1966) Insulin, insulin antibody and glucose in plasma of newborn infants of diabetic women. Acta Endocrinol (Kbh) 52: 154-167

3. Starzyńska R, Seniow S, Kodejszko E, Kowalski H, Starzynski S, Depowska B (1969) Studies on the transport of insulin antibodies across the placenta to the fetus and their effect on the fetal pancreatic islet system. Acta Diabetol Lat 6: 573-584

4. Persson B (1975) Treatment of diabetic pregnancy. Isr J Med Sci 11: 609-616

5. Block MB, Pildes RS, Mossabhoy NA, Steiner DF, Rubenstein AH (1974) C-peptide immunoreactivity (CPR): A new method for studying infants of insulin-treated diabetic mothers. Pediatrics 53: 923-928

6. Phelps RL, Freinkel N, Rubenstein AH, Kuzuya H, Metzger BE, Boehm JJ, Mølsted-Pedersen L (1978) Carbohydrate metabolism in pregnancy. XV. Plasma C-peptide during intravenous glucose tolerance in neonates from normal and insulin-treated diabetic mothers. J Clin Endocrinol Metab 46: $61-68$

7. Persson B, Gentz J, Lunell NO (1978) Diabetes in pregnancy. In: Scarpelli EM, Cosmi EV (eds) Reviews in perinatal medicine, vol 2. Raven Press, New York, p 1-55

8. Persson B, Feychting H, Gentz J (1975) Management of the infant of the diabetic mother. In: Sutherland HW, Stowes JM (eds) Carbohydrate metabolism in pregnancy and the newborn. Livingstone, Edinburgh, p 232-248

9. Christiansen, $\mathrm{AaH}$ (1973) Radioimmunoelectrophoresis in the determination of insulin binding to IgG. Methodological studies. Horm Metab Res 5: 147-154

10. Heding LG (1972) Determination of total serum insulin (IRI) in insulintreated diabetic patients. Diabetologia 8: 260-266

11. Heding LG (1975) Radioimmunological determination of human C-peptide in serum. Diabetologia 11: 541-548

12. Heding LG (1977) Specific and direct radioimmunoassay for human proinsulin in serum. Diabetologia 13: 467-474

13. Martin FIR (1976) Absolute neonatal insulin levels in children of insulin-requiring diabetic patients. Am J Obstet Gynecol 125: $71-72$

14. Stimmler L, Brazie JV, O'Brien D (1964) Plasma-insulin levels in the newborn infants of normal and diabetic mothers. Lancet I: $137-138$

15. Thomas K, de Gasparo M, Hoet JJ (1967) Insulin levels in the umbilical vein and in the umbilical artery of newborns of normal and gestational diabetic mothers. Diabetologia 3: 299-304

16. François R, Picaud JJ, Ruitton-Ugliengo A, David L, Cartal MJ, Bauer D (1974) The newborn of diabetic mothers. Biol Neonate 24: 1-31

Received: July 25, 1979,

and in revised form: July 2, 1980

Lise G. Heding

Novo Research Institute

Novo Alle

DK-2880 Bagsvaerd

Denmark 